DOI: $10.20472 / S S .2017 .6 .1 .001$

\title{
REFUGEE CRISIS IN EUROPE (2015-2016): THE CLASH OF INTERGOVERNMENTAL AND SUPRANATIONAL PERSPECTIVES
}

\author{
DOGACHAN DAGI
}

\begin{abstract}
:
The refugee crisis of 2015-2016 exposed structural difficulties in decision making for the European Union on critical issues that was deemed 'existential' for its member states. The emerging balance between intergovernmentalism and supranationalism tilted toward the former at the expense of the latter contriving to the post-Maastricht trend. Member states and the supranational EU institutions have been divided in their approach to the refugee crisis viewing it as either a national security or a human security issue. This clash of perspectives, it is argued, may not only slow the pace of integration but it is also likely to reverse the spillover affects achieved so far. Thus, the most feasible and likely response for the EU is to seek a middle way between the views of the EU actors who prioritize the refugee crisis as primarily a human security issue and those who regard it firstly as a national security issue.
\end{abstract}

\section{Keywords:}

European Union, refugees, decision making, intergovernmentalism, supranationalism, human security, national security

JEL Classification: F51, F59, H77

\section{Authors:}

DOGACHAN DAGI, 1994, Turkey, Email: dogachan.dagi@ug.bilkent.edu.tr

\section{Citation:}

DOGACHAN DAGI (2017). Refugee Crisis in Europe (2015-2016): The Clash of Intergovernmental and Supranational Perspectives. International Journal of Social Sciences, Vol. VI(1), pp. 1-8., 10.20472/SS.2017.6.1.001 


\section{Introduction}

The process of European integration has proved itself to be a unique story of economic miracles, sustained development, social transformation, enduring peace, cooperation, compromise and interdependence. Regardless of its unrivaled achievements the European project has also encountered failures, inabilities, miscalculations, disagreements and crisis. The first major crisis the EU had witnessed in the new millennia was the non-ratified Constitutional Treaty of 2004 which received two negative referendums in France and Netherlands ${ }^{1}$, demonstrating the rising Euro-skepticism even within the founding members of the European Coal and Steel Community while also making clear the limits of furthering the integration process (Ultan \& Ornek 2015). The European debt crisis that erupted in the late 2009 was the second major setback for the credibility of the EU, especially since it was seen as a sign of how prone the Union (as among the largest economies in the world ${ }^{2}$ ) was to external influences and financially divided internally. However, it wasn't until the refugee crisis of 2015-2016 that the European Union with all of its member states and supranational and intergovernmental institutions was caught in such a vulnerable and exposed position.

\section{European (Dis)integration in the Face of Refugee Crisis}

The humanitarian crises in Syria, Iraq and Afghanistan -which the EU had no direct involvement in the commencement of the intrastate conflicts- marked legal and moral obligation for the Union to face the burden of migrants seeking refuge to a community that they wholeheartedly regarded as most preferable due to its respect to human rights and the economic opportunities it provides. ${ }^{3}$

Despite the fact that historically EU had grown even stronger in the each aftermath of major confrontations it faced, this essay strongly argues that the refugee crises of 2015-2016 must be considered sui generis as the consequences of migration are bound to remain highly complex within the context of demographics, politics, sociology, social psychology and economics. The intergovernmental nature of the problem makes a common response that will serve to the benefit of all politically and culturally diverse member states almost impossible as concerns on national interests are likely to trump over the common EU interests. Thus, the ongoing refugee crisis does not only slow the pace of integration it also reverses the spillover affects achieved so far. Even though conducting a common European response to this issue is highly unlikely (but also necessary), the most feasible response would be the one that seeks a middle way between the views of the member states that prioritize the refugee crises as primarily a human security issue and with those who regard it as a national security issue. Yet, this compromise should not only involve member states but also include constructed EU norms in the context of "state of

\footnotetext{
1 To see the background of the Constitutional Treaty: http://www.euractiv.com/section/futureeu/linksdossier/constitutional-treaty-key-elements-archived/\#ea-accordion-background

2 To see the data for the GDP of the EU:

http://www.imf.org/external/pubs/ft/weo/2014/01/weodata/weorept.aspx?pr.x=46\&pr.y=16\&sy=2014\&ey=2014\&sort=co untry\&ds $=. \& b r=1 \& c=998 \& s=N G D P D \% 2 C P P P G D P \& g r p=1 \& a=1$

3 To have an opinion on the refugees motivation for a life in the EU see:

http://www.telegraph.co.uk/news/worldnews/europe/11845205/Why-do-refugees-and-migrants-come-to-Europe-andwhat-must-be-done-to-ease-the-crisis.html
} 
emergency" which will require new regulations passed for making sure that the refugees are to be fully integrated to the culture of their place of residence.

With over a million illegal migrants ${ }^{4}$ and 1.2 million asylum applications in 2015, a vast majority being from the war thorn countries stated $a b o v e^{5}$, a number more than double that of the last year, the European policy makers and public were paralyzed paving the way for unilateral and incoherent steps to be taken. Anyhow, the question of how to react to mass migration is an old topic of discussion for the European integration project, dating back to early 1970 s as the number of foreign workers (mostly of Turkish origin) in western Europe doubled from $\% 3$ to $\% 6$ of population in a decade. ${ }^{6}$

\section{Attempts to Formulate a Common Response}

To understand current refugee crisis a historical perspective may be needed. The internal context of the founding principles of the European Community as well as the global context of universal human rights ensured a liberal and unsecuritized action to be taken on asylum seeking at the supranational level of governance. To be more precise, the dedication of the European Community to the Preamble of the UN Charter and the Universal Declaration of Human Rights affected the nature of policies to be implemented at the European Commission level (EU 2013). The key legal document that defined who a refugee is, what their rights and the legal obligations of States are, however, was the Geneva Convention of 1951, along with its 1967 Protocol which removed geographical and temporal restrictions from the Convention (UNHCR 2011). These legal documents of international law that meant significant limitations to the states' right for the closure of borders helped minimize the possibility of the European to initiate strict migration control tools and deportation legislations (Guild 2003).

Surely, the European policy makers committed to the European cause in each level of governance were aware of the external threat of mass immigration to the internal process of integration and spillover. Such a sensitive issue contained a high risk of reversing this ambitious comment made by the Commission:

"The European Union is well placed to promote democracy and human rights[...]Uniquely amongst international actors, all fifteen states of the Union are democracies espousing the same Treaty-based principles in their internal and external policies. This gives the EU substantial political and moral weight. [...] the European Union has both influence and leverage, which it can deploy on behalf of democratization and human rights." (Balfour 2006)

For this very reason the European Commission pursued an agenda of externalization of control tools in which sending development aid to the countries where the refugee flow originated was the key for an endeavor to minimize the root of migration instead of internal

\footnotetext{
${ }^{4}$ Check for more information: http://www.economist.com/news/briefing/21690066-europe-desperately-needs-controlwave-migrants-breaking-over-its-borders-how

${ }^{5}$ Check for more information: http://www.bbc.com/news/world-europe-34131911

${ }^{6}$ For more information see:

http://www.oecdobserver.org/news/archivestory.php/aid/337/Immigration_in_the_European_Union:_problem_or_solutio n_.html
} 
policies of strict policing and patrolling (Boswell 2003). Moreover another historical achievement that concerned the refugee rights -although indirectly- was reached with the Article II of the Treaty on European Union (1992) that formulated the EU's founding values as 'human dignity, freedom, democracy, equality, the rule of law and respect for human rights, including the rights of persons belonging to minorities'. ${ }^{7}$ Also, the Amsterdam Treaty of 1997 moved the cooperation on immigration and asylum from the third pillar of Justice and Home Affairs (which was an intergovernmental policy making area as decided in the Maastricht Treaty of 1992) to the supranational first pillar of European Communities (Boswell 2003). Additionally, the Treaty of Amsterdam confirmed that the member states shall refrain from any action contrary to the interests of the Union or likely to impair its effectiveness as a cohesive force in international relations (Taylor 2008). This was essentially a -failed- pledge to limit the restrictive measures taken by the member states.

On the other hand, the debates regarding immigration and asylum were far away from being a sole concern within the principle of universal human rights. The principle of national sovereignty is still of crucial importance in a Westphalian world system-despite the claims that the Geneva Conventions is a direct legal limitation of state sovereignty (Guild 2003). Even in the context of EU in which the member states agreed upon pooling their sovereign rights in a number of policy areas to a supranational level of governance there have historically been discrepancies between the supranational institutions of the Community, namely the European Commission, and the intergovernmental institutions, like the European Council and the Council of Ministers. Not surprisingly, the former had a tendency on viewing the issue as firstly a matter of universal human rights where securitization would be against European values while the latter had intentions on prioritizing the issue as a matter of national sovereignty where securitization was needed in order to protect European values.

Therefore, the external dimension of the Commission initiated immigration and asylum policy that focuses on the exportation of classical migration control instruments to third world countries while also addressing the 'root causes' of migration and refugee flows was not formally embraced by the European Council until 1999. Two main reasons might be spelled out for how this agreement was reached and why it took so long. First of all, the Council is likely to regard the initiative for eliminating the root causes of mass refugee flows via aiding the third world countries as a futile enterprise that seems too idealistic (Hall 2000). Secondly, the Council seems persuaded that domestic border controls are inadequate in stopping illegal migration (Boswell 2003). However, the bargain was not one sided but again a compromise. It was agreed that cooperation on migration management should be done as subordinate to the externalization strategy (Boswell 2003). There were two noteworthy reasons for such a compromise to be reached: one was the traditional reservations of the European Council in excluding security measures and the other one was the reaction in European public discourse to the change in demographics. The rise of far right political parties, and center right parties promising to limit migration since the early $1990 s^{8}$ in altered the scope of this policy area dramatically. Combined with the security threat perceived in the form of Islamic terrorism, the issue was from now on not only about

\footnotetext{
7 To see the whole treaty: http://www.europarl.europa.eu/atyourservice/en/displayFtu.html?ftuld=FTU_6.4.1.html

8 To see the list of emerging far right parties throughout EU: http://www.theguardian.com/gall/0,,711990,00.html
} 
the financial burden of refugees but it was also about social and cultural concerns with more substance.

\section{Obstacles to a Common Refugee Policy}

Concerning that the immigration policy of the EU had traditionally been juvenile and inconsistent (Soysal 1993) it came as no surprise that no common policy could be utilized in the wake of mass refuge crisis. Instead, the member states were -almost without any exception- engaged in unilateral ad hoc measures. This included a variety of actions from the construction of border barriers in the Hungarian-Serbian border ${ }^{9}$ to the temporary suspension of Schengen visa policy by Austria. ${ }^{10}$ As the political salience of the topic increases in the public a restrictive approach towards refugee rights is more likely (Luedtke \& Givens 2004) which will be in accordance with the prioritizing of national concerns over Community concerns. This creates a vicious circle as the topic becomes more and more intergovernmental making the possibilities for a common European response highly unlikely. Thereby, the integration furthered with the Amsterdam Treaty of 1997 that also aimed for a more supranational response to the refuge policies (whether it was ever achieved is open to question) have at the moment been totally void.

Moreover, a supranational response is very unsound since it contains the risk of agitating a number of member states that might suffer in relative terms. Besides, the signature achievement ${ }^{11}$ of the European integration project since 1985, the Schengen Visa Policy that allows for the freedom of movement of the nationals of member countries, is at grave danger. Angela Merkel, the chancellor of Germany warned the Europeans that Schengen could be at risk if all the member states refuse to take their share of refugees. ${ }^{12}$ Also, the Dublin Convention signed in $1990^{13}$-now commonly known as the Dublin Regulationshave caused enormous dilemmas for the Schengen regime. The secondary movements of the refugees from their country of entry violated the Dublin Regulations as it eliminated border controls within the EU, but it also exposed the member states in the Mediterranean which are the gates of entry for the refugees. ${ }^{14}$

Furthermore, the massive influxes of refugees witnessed in the last two years have caused categorical disagreements at the level of member states, in an already politically divided community. The continuation of this dispute might lead to opt-outs from the JHA by the V4, further derailing the integration process (Hokovsky 2016). While Germany and Sweden conducted an open door policy ${ }^{15}$, the Central European countries were much more skeptical in regards to a full-fledged pro refugee policy. For instance, Slovakia, Czech Republic, Hungary and Poland have all expressed that are willing to take non-Muslim

\footnotetext{
9 To see details: http://www.kormany.hu/en/ministry-of-defence/news/reinforcement-of-temporary-security-barrierstarts-on-the-hungarian-serbian-border

${ }^{10}$ To see details: http://www.politico.eu/article/austria-suspends-schengen-border-checks-eu-migrants/

11 More here: http://www.politico.eu/article/what-is-schengen-explainer-borders-europe-free-movement/

12 Read here: http://www.politico.eu/article/merkel-warns-schengen-at-risk-germany-refugees-migration-quotas-travel/

${ }^{13}$ Read full text here: http://eur-lex.europa.eu/legal-content/EN/ALL/?uri=CELEX\%3A41997A0819(01)

14 See more: http://www.aljazeera.com/news/2016/02/macedonia-greek-border-faces-humanitarian-challenge160228135807844.html

${ }^{15}$ For details: http://www.telegraph.co.uk/news/worldnews/europe/sweden/11992479/How-Sweden-the-most-opencountry-in-the-world-was-overwhelmed-by-migrants.html
} 
migrants ${ }^{16}$ which is actually a grave violation of the EU`s nondiscrimination laws ${ }^{17}$. The recent crises and the dissatisfactory response to it by Germany and the Commission brought together the Visegrad Group once again after their acceptance to the EU. The Group of Poland, Hungary, Czech Republic and Slovakia expressed their mutual concern that the EU had lost control of the frontiers of the passport-free Schengen zone (Cienski 2016). Consequently, the Visegrad countries share the assumptions that efforts to integrate Muslim immigrants in Europe have failed, migration crises are not uncontrollable and the migrants will not bring economic benefits (Hokovsky 2016). Likewise, the Central European countries have demanded for a permanent barrier on Greece`s northern border stating that Greece is willfully breaching its responsibilities as an EU border state by allowing undocumented migrants. ${ }^{18}$ The range of opinions by the European policy makers are at best irreconcilable in this issue. The Visegrad Group expressed that:

"A swift implementation of measures [...] to strengthen external border protection must remain the top priority if we are to prevent the 2015 scenario [...] A crises that questions the very foundations of the European Union." (Foy 2016)

Meanwhile, Heather Conley pointed out:

"Such policies would not just imperil migrants and refugees, but also the very ideals upon which the EU was found. The political response [...] runs counter to the very values that the EU promotes, like protecting human life and the right to asylum." (Park 2015)

Moreover, the perceived threat of cultural conflict and demographic change combining with the frustration caused by lack of common response reveals a fertile ground for the populist right wing parties to attract attention. This doesn't only account for a temporary reaction but can stand for an agenda changer. The local election on the $6^{\text {th }}$ of March 2016 in the German state of Hesse in which the far right Alternative für Deutschland Party managed to win 17 per cent of the vote demonstrates that a growing number of Europeans are dissatisfied with the European political mainstream. ${ }^{19}$ Likewise, the debate on migration and its burden on the UK has been a decisive factor in the Brexit referendum of June 2016 that has demonstrated growing sentiment in Europe in favor of setting limitations on immigration.

\section{The Way Forward}

Traditionally, areas concerning national security and foreign policy (high politics) have been strictly intergovernmental and no substantial step for integration could have been taken. Therefore, in the face of this major crisis a supranational initiative carries numerous risks. Even though political entrepreneurship by the European Commission as well as judicial activism by the European Court of Justice have a potential of transforming the EU into an even stronger entity, (turning the crises into opportunity) it might also reverse the

\footnotetext{
${ }_{16}$ See more: http://www.cfr.org/migration/europes-migration-crisis/p32874

17 To have a precise idea on EU's non-discrimination policies: http://fra.europa.eu/sites/default/files/fra_uploads/1510FRA-CASE-LAW-HANDBOOK_EN.pdf

${ }^{18}$ See more at: https://next.ft.com/content/c15b28f2-d425-11e5-8887-98e7feb46f27

${ }^{19}$ For more information: http://www.independent.co.uk/news/world/europe/germany-local-elections-far-right-groupsmerkel-afd-npd-huge-gains-a6917246.html
} 
achievements reached so far. Thus, conducting a common response through intergovernmental bargaining is more feasible despite the fact that its success might be less satisfactory. For a common response to be agreed upon, however, the member states should engage in what they were best at, which is compromise. European Union should take into account the concerns of policy makers on both human security and national security. Intergovernmental Conferences should be planned in an endeavor to reconcile the notion of universal human rights with the notion of national sovereignty, and any result taken should be unanimous for a sign of European synergy. The predicted result would make no member state, no NGO and no politician totally happy but at the same time it will not make any one frustrated. To be more precise, the refugees that entered the Schengen Zone should be distributed proportionately within the EU members that authorized the Schengen visa. This will make unilateral measures pointless since eventually a significant amount of the refugees will be sent to other member states. Additionally, the EU should be more reluctant to give asylum and should focus its efforts on aiding the refugee hotspots in Turkey, Lebanon, Jordan etc. Moreover, especially after the Paris \&Brussels terror attacks the budget of EUROPOL should be increased and any suspicion of individual or group radicalization should be carefully policed. Regulations from the OLP should be passed to make sure the refugees are to integrate with the local culture, and radicalized individuals should not be tolerated.

The refugee crises of 2015-2016 have caused a third shock wave for the European Union in the $21^{\text {st }}$ century, which appeared to be an existential threat for the integrity of the Union. Partly due to the lack of agreed principles beforehand and partly due to the unprecedented magnitude of the refugees no effective policy could be utilized to counter this issue in any governance level of the EU umbrella. Yet, to avoid an external problem reversing the success of internal integration, the European policy makers have to find a common ground to agree upon and demonstrate that member states refrain from any action which is contrary to the interests of the Union.

\section{References}

BOSWELL, CHRISTINA. (2003). "The 'external dimension' of EU immigration and asylum policy." International Affairs, 79(3): 619-638. https://doi.org/10.1111/1468-2346.00326

CIENSKI, JAN. (2016)."Central Europe wants to halt migration if EU plan fails." Politico, February 15, 2016. http://www.politico.eu/article/migrants-asylum-orban-visegrad-poland-hungary-chezch-slovakiamigration-refugees/ (accessed April 20, 2016).

EU. EUEA. 2013. http://eeas.europa.eu/organisations/un/index_en.htm (accessed April 20, 2016).

FOY, HENRY. (2016). "Central Europe states keep migrant heat on Athens." Financial Times, February 16, 2016. https://next.ft.com/content/c15b28f2-d425-11e5-8887-98e7feb46f27 (accessed April 20, 2016).

GUILD, ELSPETH. (2003). "International Terrorism and EU Immigration, Asylum and Borders Policy: The Unexpected Victims of 11 September 200." The European Foreign Affairs Review. 8:331-346.

HALL, BEN. (2000). "Immigration in the European Union: problem or solution? ." Prospect Magazine, June $20,2000$.

HOKOVSKY, RADKO. (2016). "How migrants brought Central Europe together." Politico. http://www.politico.eu/article/how-migrants-brought-central-europe-together-visegrad-group-orbanpoland/ (accessed April 20, 2016). 
BALFOUR, ROSA. (2006). "Principles of Democracy and Human Rights: a review of the European Union's strategies towards its neighbours ." In Values and Principles in European Union Foreign Policy. edited byLucarelli, Sonia \& Manners, Ian.. New York: Routledge.

LUEDTKE, ADAM \& GIVENS, TERRI . (2004). "The Politics of European Union Immigration Policy: Institutions, Salience, and Harmonization." The Policy Studies Journal 32 (1):145-165. https://doi.org/10.1111/j.0190-292X.2004.00057.x

PARK, JEANNE. (2015). Europe's Migration Crisis. Council on Foreign Relations. September 23, 2015. http://www.cfr.org/migration/europes-migration-crisis/p32874 (accessed April 20, 2016).

SOYSAL, YASEMIN. "Immigration and the Emerging European Polity." In Making Policy in Europe: The Europeification of National Policy-making. Editedby S. Andersen \& K. Eliassen. London: SAGE Publications, 1993.

TAYLOR, PAUL. (2008). The End of European Integration: Anti-Europeanism Explained . New York: Routledge.

TILFORD, SIMON. (2016). Britain, immigration and Brexit. Centre for European Reform, CER Bulletin,.

ULTAN, MEHLIKE OZLEM \& ORNEK, SERDAR. (2015). "Euroscepticism in the European Union." International Journal of Social Sciences IV:2.

UNHCR. (2011). The 1951 Convention Relating to the Refugees and its 1967 Protocol. 